\title{
REBUILDING SCHOOLS, REBUILDING COMMUNITIES: THE CIVIC ROLE OF MISSISSIPPI'S PUBLIC SCHOOLS AFTER HURRICANE KATRINA
}

\author{
Kristi L. Bowman ${ }^{*}$
}

\begin{abstract}
- Assistant Professor of Law, Michigan State University College of Law. This article is an excerpt of a chapter originally published in CHILDREN AND DISASTERS: WHAT We Have Learned From The HuRricanes of 2005 (forthcoming 2008) and is reprinted with the permission of the Center for Children, Law \& Policy at the University of Houston Law Center, and the American Bar Association Center on Children and the Law. Those two organizations hosted an outstanding conference in April 2007: "Children and Law After the Katrina Disaster: An Interdisciplinary Conference on Young Evacuees," at which an earlier version of this article was presented. This article also was presented at the 2007 Law and Society Association annual meeting and benefited from comments by fellow panelists and colleagues at both conferences.

I also am grateful to the University of Mississippi School of Law for providing support for on-site research in October 2006 during my year as a visiting member of that faculty; to the Michigan State University College of Law Library staff for exceptional research assistance by Joseph Dunn under the supervision of Jane Edwards and Barbara Bean; to University of Mississippi colleagues Debbie Bell, Tom Burnham, Susan Glisson, Andy Mullins, and Farish Percy for providing information about and contacts with Gulf Coast educators and community activists; to Kate Dennis and Alysson Mills for editorial assistance; and last but certainly not least to the following Mississippi educators for sharing their time and providing thoughtful reflections about the long arm of the storm and the recovery process: State Superintendent Hank Bounds, Pascagoula High School Guidance Counselor Herb Brown, Gulf Coast Education Initiative Consortium Executive Director Tom Clark, Mississippi Center for Justice attorney Kim Duffy, Gulfport School District Superintendent Glen East, Gulfport Assistant Director of Special Education Steve Huckabee, Bay St. Louis-Waveland Assistant Superintendent Becky Ladner, Gulfport Director of Special Education Martha Mullins, Harrison Central High School teacher Carol Rayburn, Jackson County School District Superintendent Rucks Robinson, Pascagoula School District Superintendent Wayne Rodolfich, and
\end{abstract}


Schools like Second Street Elementary [in the Bay St. LouisWaveland School District] have become the glue that holds this fractured community together. ${ }^{1}$

When public elementary and secondary schools in the six Mississippi Gulf Coast-area counties opened in August 2006, they enrolled ninety-two percent of the number of students they had before Hurricane Katrina made landfall just one year earlier. ${ }^{2}$ Some of these students were Louisiana evacuees ${ }^{3}$ and others were children of construction workers, but most were children who had lived in the area all along. The one-year return rate in Mississippi's Gulf Coast public schools varied among districts depending on the extent of damage, ${ }^{4}$ but coastal Mississippi's return rate was nearly double New Orleans'. Although many of Katrina's lessons tell us what government did (or, more often, failed to do) with an unforeseen and heartbreaking level of ineptness, some lessons from Mississippi school districts-yes, from schools in a state known for having one of the most quantitatively weak public school systems in the country ${ }^{5}$-also can tell us what government did exceptionally well. After Katrina, Mississippi public school districts' herculean efforts to reopen public schools within a matter of weeks helped to anchor their communities and enable

Pascagoula School District Assistant Superintendent for Administration Gary Tierce. Any errors are, of course, my own.

1 The News Hour with Jim Lehrer (PBS television broadcast Apr. 6, 2006).

2 Telephone Interview with Hank Bounds, State Superintendent of Educ. for Miss. (Aug. 2006). Three of these Mississippi counties--Hancock, Harrison, and Jackson-are directly on the coast and the three others-George, Pearl River, and Stone-are immediately to their north. Although all six counties suffered substantial damage from Katrina, the damage obviously was more dramatic for the three coastal counties. Thus, the comparison to New Orleans is not an apples-to-apples comparison.

${ }^{3}$ About ten percent of the displaced Louisiana residents took shelter in Mississippi. LOUISIANA RECOVERY AUTHORITY, HURRICANE KATRINA ANNIVERSARY DATA FOR LOUISIANA 2 (Aug. 20, 2006), available at http://www.lra.louisiana.gov/assets/Louisiana KatrinaAnniversaryData082206.pdf.

4 Compare The News Hour (Apr. 6, 2006), supra note 1, with The News Hour with Jim Lehrer (PBS television broadcast Mar. 20, 2006).

5 EDUC. WEek RESEARCH CTR., MISSISSIPPI STATE INFORMATION (2006), available at http://www.edweek.org/rc/states/mississippi.html (last visited Dec. 5, 2006); Jimmie Covington, State Raising Bar on Public Education, MEMPHIS COMM. APPEAL, Sept. 30, 2006, at B6. 
significant recovery to begin and then progress. This article chronicles that story. ${ }^{6}$

Although Katrina came ashore in Mississippi and the destruction of buildings and personal property there was described as "more complete" than in Louisiana, ${ }^{7}$ Katrinarelated media coverage and public attention focused heavily on New Orleans. I do not intend to suggest that some of the disproportionate focus is not justified; the sheer number of people who were stranded, who died, who were rendered homeless as a result of these disasters was substantially higher in New Orleans than in coastal Mississippi. Yet, no matter how many media accounts I read, the scope of the damage in Mississippi was incomprehensible to me until I saw it. Putting the damage in perspective, two weeks after Katrina a reporter wrote in the New York Times:

If the levees had held in New Orleans, the destruction wrought on the Mississippi Gulf Coast by Hurricane Katrina would have been the most astonishing storm story of a generation. Whole towns have been laid flat, thousands of houses washed away and, statewide, the storm has been blamed for the deaths of 211 people, a toll far higher than those from Hurricanes Andrew, Hugo and Ivan. ${ }^{8}$

\footnotetext{
6 Vivian L. Gadsen and Susan Fuhrman write,

While news reports highlight the conditions of these displaced children and families and, more recently, of the increased crime waves in cities such as Atlanta and Houston (described as a by-product of the relocation), fewer reports have addressed issues of education and schooling-either the efforts of the schools and school districts that now house the Gulf Coast region's displaced or the plans of local agencies in the Gulf Coast region to address the needs of displaced/returning students and their families. One can imagine that an assumption guiding current efforts is that once housing and other basic needs are addressed adequately, the reorganization of the schools and educational systems will follow. This assumption is problematic.
}

Reflections on Educational Equity in Post-Katrina New Orleans, in SHARON P. ROBINSON $\&$ M. CHRISTOPHER BROWN, THE CHILDREN HURRICANE KATRINA LEFT BEHIND 77 (2007). See also S. Educ. Found., Education AfTer Katrina: Time fOR a NEW FEderal RESPONSE (2007); STENNIS INST. OF GOV'T, SPECLAL REPORT: A LOOK AT RECOVERY, Roles, AND CAPACITY OF Mississippi CoAstal SchOOL Districts STRUGGLING AND REBOUNDING AFTER HURRICANE KATRINA (2006).

7 Jim Lewis, Battle for Biloxi, N.Y. TIMES MAG., May 21, 2006, at 100.

8 Campbell Robertson, Coastal Cities Of Mississippi In The Shadows, N.Y. TIMES, 
Recognizing what has happened in Mississippi is a crucial part of understanding Katrina's full impact as we reflect on the many aspects of this disaster, and also an important part of absorbing what lessons we can from Katrina and using that knowledge to plan better for future disasters. ${ }^{9}$ As the Southern Education Foundation recognized, repairing and reopening public schools was often not a high priority for Federal Emergency Management Agency (FEMA) officials. ${ }^{10}$ We must not allow that mistake to be repeated.

\section{The CoAstal Mississippi Public Schools: Before KATRINA, AND KATRINA's DAMAGE}

In the years leading up to Katrina, the Mississippi Gulf Coast schools had been gaining ground. The region had become known as one of Mississippi's stronger, educationally speaking. The current state superintendent came directly from the superintendency of one of the coastal districts, ${ }^{11}$ as did his predecessor. The region's schools were supported by an upwardtrending tax base ${ }^{12}$ in what is for the most part a very propertypoor state. ${ }^{13}$ During the 1990 s, the gaming industry took root along coastal Mississippi, eventually leading to the opening of at least a dozen off-shore casinos which brought about 30,000 jobs to the area and hundreds of millions of dollars in state and local tax revenues every year-the "Mississippi Miracle." ${ }^{4}$ The

Sept. 12, 2005, at $1 \mathrm{~A}$.

9 RAND Gulf States Policy Institute, Fact Sheet, Preparing for Future Floods: Analyzing Reconstruction Pathways from Past Floods Can Help (2006).

10 S. EdUC. Found., EdUCATION AFTER KATRINA, supra note 6, at 20.

11 Available at http://www.mde.k12.ms.us/MDEDirectory/Superin.htm.

12 "[A]lmost all school districts on the Mississippi coast had healthy budgets and test scores above the state average. Half of Mississippi's coastal schools were ranked by the state as 'exemplary' or 'superior." S. EDUC. FOUND., EDUCATION AFTER KATRINA, supra note 6 , at 7 .

13 See generally Sharon D. Wright Austin, The Transformation of Plantation Politics 61.66 (2006); Heifer Foundation, North America: Mississippi Delta Endowments (2007), available at http://www.heiferfoundation.org/waystogive/country /northamerica/MississippiDelta.cfm; Debbie Elliott, Reviving Mississippi Delta a Long, Slow Process, All Things Considered (NPR braodcast June 7, 2005), available at http:// www.npr.org/templates/story/story.php?storyId=4679733.

14 The News Hour with Jim Lehrer (PBS television broadcast Oct. 17, 2005); The 
growing commercial tax base supplemented the residential tax base, which included some stately beachfront homes such as Senator Trent Lott's. ${ }^{15}$ An Atlanta doctor who moved to Mississippi during the recovery described pre-Katrina Mississippi as "an up-and-coming place. This wasn't the Mississippi of the history books. [Before Katrina, it] was casinos, resorts, high-tech. In a state with awful schools, the schools here were pretty good." 16

Then Katrina hit. The more-than-thirty-foot storm surge retreated within a matter of hours from most of Mississippi. ${ }^{17}$ State officials estimated that about six percent, or 30,000 , of their public school students were displaced by Katrina. ${ }^{18}$ The United States Department of Education reported that, across the region, over one thousand schools were closed for at least two weeks. ${ }^{19}$ The Southern Education Foundation described this as the largest displacement of students from schools since the Great Depression. ${ }^{20}$ Eventually, Katrina resulted in deaths of 231 Mississippians $^{21}$ and 1464 Louisiana residents. $^{22}$ About three hundred Mississippi public schools were severely damaged, including twenty-four that were destroyed. ${ }^{23}$ Mississippi Gulf Coast public schools also lost 150 buses. ${ }^{24}$ State

News Hour with Jim Lehrer (PBS television broadcast Aug. 25, 2006); Robertson, Coastal Cities, supra note 8, at A1.

15 Available at http://www.cnn.com/2005/POLITICS/08/30/katrina.lott.

${ }_{16}$ Claudia Dreifus, Attending to Sick Children Along a Gulf Coast Still in Tatters, N.Y. Times, Nov. 21, 2006, at F2.

17 Lewis, Battle for Biloxi, supra note 7, at 100.

18 Bounds Interview, supra note 2; Irwin Redlener, Orphans of the Storm, N.Y. Times, May 9, 2006, at A27. During the 2004-2005 school year, 495,376 students were enrolled in Mississippi public schools. National Center for Education Statistics, State Education Data Profiles (data taken from the Common Core of Data), available at http://nces.ed.gov/programs/stateprofiles/sresult.asp?mode=short\&s1=28.

19 U.S. Dep't of Educ., Helping Gulf Coast Students Read and Succeed (Apr. 2007), available at http://hurricanehelpforschools.gov/030206-factsheet.html.

20 S. EdUC. FoUND., EdUCATION AFTER KATRINA, supra note 6, at 3.

21 Joshua Norman, Toward a Comprehensive Death Count, SUN HERALD, Nov. 18, 2006, at A9.

${ }^{22}$ La. Dep't of Health and Hosps., Reports of Missing and Deceased (Aug. 2, 2006), available at http://www.dhh.louisiana.gov/offices/page.asp?ID=192\&Detail=5248.

23 Bounds Interview, supra note 2.

24 Covington, State Raising, supra note 6, at B6. 
Superintendent Hank Bounds estimated that the total damage suffered by Mississippi public school districts exceeded $\$ 800$ million $^{25}$-when a hurricane strikes, it is not only buildings that need repair, but also desks, chairs, textbooks, libraries, technology, and other equipment that often must be replaced in their entirety.

After Hurricanes Katrina and Rita hit, the federal government allocated approximately $\$ 750$ million in elementary and secondary school restart funding to supplement FEMA and state-based emergency relief funding. ${ }^{26}$ Louisiana received $\$ 445.6$ million of this total; Mississippi, $\$ 222.8$ million (distributed to thirty-eight school districts); Texas, $\$ 78.2$ million; and Alabama, $\$ 3.8$ million. The federal government also provided impact aid to school districts in the region and across the country that absorbed the displaced students from the coast. ${ }^{27}$ In Mississippi, this impact aid was supplemented by a five-million dollar investment by the Bill \& Melinda Gates Foundation. ${ }^{28}$

\section{MISSISSIPPI's RECOVERY}

\section{A. Mississippi Schools' Role in Providing Emergency Relief}

In the days following the storm, displaced residents' most acute physical needs were food and housing. A number of public schools in the Gulf Coast region survived well enough to serve as emergency shelters until the days, or more often weeks, when FEMA trailers arrived. ${ }^{29}$ During this time, some residents were

\footnotetext{
25 Bounds Interview, supra note 2.

${ }^{26}$ Alyson Klein, Schools Get Katrina Aid, Uncertainty, EDUC. WEEK 1, 29 (Mar. 29, 2006).

${ }^{27}$ Id.

${ }^{28}$ Press Release, Miss. Dep't of Educ., New Investment to Help Improve Quality of Education for Mississippi Students and Schools Affected by Katrina (Dec. 16, 2005), available at http://www.mde.k12.ms.us/extre//news/Gates\%20Foundation\%20Grant.htm.

${ }^{29}$ Interview with Rucks Robinson, Jackson Co. Sch. Dist. Superintendent, in Vancleave, Miss. (Oct. 20, 2006). Many religious communities and community organizations (such as the Girl Scouts) also provided their facilities for use as emergency shelters. See http://www.arkansasoutreach.com/arkansas_katrina_emergency_shelt. htm.
} 
able to make arrangements to live with friends or family members, others decided to leave the area, and many remained in need of emergency shelter. The emergency shelter provided by the schools was invaluable; yet, allowing schools to be used as large-scale shelters was not cost-free to the educational process. The occupancy of the schools and then the necessity of cleaning them inevitably pushed back the date by which the schools could be ready to reopen. ${ }^{30}$

The idea of using schools as emergency shelters is hardly novel-indeed, California disaster plans, anticipating earthquakes, identify school buildings as sites for emergency shelters. ${ }^{31}$ This makes a good deal of sense: in most communities, the largest government buildings open to the public are city and county administrative offices, public libraries, community activity centers, courthouses, and public schools. ${ }^{32}$ Of these, schools often have the most open or potentially open space in which cots can be set up because of their gymnasiums and lunchrooms, and also because student desks in most classrooms are fairly easy to move, compared to cubicles and office furniture. School buildings also have large kitchen and restroom facilities. Additionally, most "official" government buildings are concentrated in one area in a community, whereas schools are more dispersed throughout a community. ${ }^{33}$ A city center might be hit hard (as in Pascagoula,

30 Robinson Interview, supra note 29; Vicki Smith, Officials Plan to Move Evacuees From Some Schools; Showers Arrive, Associated PRESS STATE \& LOCAL WIRE, Sept. 14, 2005.

31 Ted Nordhaus \& Michael Shellenberger, Preparing for Nature's Attack, N.Y. TIMES, Apr. 1, 2005, at A15.

32 State and federal jails and prisons also are on this list, but many communities in hurricane-threatened areas seem to make a practice of evacuating inmates to safer ground when a potentially serious storm is approaching. State of La., Dep't of Pub. Safety \& Corrections, Office of the Secretary, A Short Story About Resourcefulness, Courage, and Two Hurricanes (date unclear). However, this practice may not have been followed in New Orleans. See Human Rights Watch, Officers Deserted a Jail Building, Leaving Inmates Locked in Cells, Human Rights News (Sept. 22, 2005); Olenka Frenkiel, Prisoners of Katrina (BBC broadcast Aug. 13, 2006).

${ }^{33}$ Sara Frye, School May Double as Hurricane Shelter, MIsS. PrESs, June 26, 2007 (noting the absence of shelters in west Jackson County, one of the three Mississippi counties directly on the Gulf, and the school district's attempts to have a new school in that area designated as an approved emergency shelter). 
Mississippi), destroying many of the local government offices, or it might be spared the brunt of the disaster. But because natural disasters vary in their effects from one community to the next and even within communities as well ${ }^{34}$ the public buildings most likely to be standing in any community after a disaster, and thus usable as emergency shelters, are public schools and community centers-and the former outnumber the latter significantly.

Thus, during the few weeks immediately after Katrina and sometimes for several months, school buildings in Mississippi and Louisiana housed many of the 230 emergency shelters the Red Cross opened in six states across the South. ${ }^{35}$ Some of these schools functioned as temporary headquarters for relief workers and for displaced local municipal government offices including the police, as well. ${ }^{36}$ (Out of necessity, some residents created shelters in schools that were not approved as shelter facilities. ${ }^{37}$ ) As weeks turned to months and groups of volunteers came to the area, they, too often were provided shelter in school gyms and in

\footnotetext{
34 See generally National Oceanic and Atmospheric Administration, Hurricane Basics (1999), available at hurricanes.noaa.gov/pdf/hurricanebook.pdf (last visited Dec. 5, 2006).

${ }^{35}$ Kate Zernike and Jodi Wilgoren, Hurricane Katrina: The Displaced, N.Y. TIMES, Aug. 31, 2005, at A1; see also Scott Canon, Displaced Hurricane Survivors Move Into New Shelters, SUN HeRAld, Sept. 18, 2005 (Mississippi school shelter); Smith, Officials Plan, supra note 31 (Mississippi school shelter); Rick Lyman and Susan Saluny, Still Sheltered, Evacuees Take a Longer View, N.Y. TIMES, Sept. 22, 2005, at A1 (Louisiana school shelters); Jodi Cararas, Northshore Harbor Center in Slidell to Become Temporary Home for Over 600 Displaced Residents, NEw ORLEANS CiTY Business, Sept. 29, 2005; Charlie Chapple, Shelters Are Being Moved From St. Tammany Schools; Classes Are Expected to Resume on Oct. 3, TTMES-PICAYUNE, Sept. 22, 2005, at B05.

36 For example, the Jackson County school district's administrative office building housed various local municipalities, as did the Pascagoula High School. Robinson Interview, supra note 29; Interview with Wayne Rodolfich, Pascagoula Sch. Dist. Superintendent, in Pascagoula, Miss. (Oct. 20, 2006); Rob Nelson, Habans Elementary Becomes Staging Area; School Becomes Officers' Home Away From Home, TIMEsPICAYUNE, Sept. 29, 2005, at 99 (Louisiana school used as headquarters and emergency shelter for over 150 police officers).

37 See, e.g., Alan Huffman, Katrina: The Aftermath: Folk seize reins, act as own rescuers, ATLANTA JOURNAL-CONSTITUTION, Sept. 25, 2005, at 3C; Vicki Smith, Mississippi Town is Seemingly Forgotten in Katrina Recovery, ASSOCIATEd PRESS STATE \& LOCAL WIRE, Sept. 20, 2005.
} 
churches. ${ }^{38}$

Now looking forward, at least two Mississippi coastal school districts are attempiting to have more of their school buildings approved for future use as emergency shelters. ${ }^{39}$ In at least one situation, a school district petitioned the Mississippi Emergency Management Authority (MEMA, the state's counterpart to FEMA) to designate a school awaiting rebuilding as an emergency shelter. If such an application is approved, the school receives additional funding from MEMA to be used in the building's construction so that the facility meets the more rigorous standards for approved emergency shelters: having emergency backup utilities and a roof and exterior design that are able to withstand two-hundred-mile-per-hour winds. ${ }^{40}$ The community would benefit by gaining an emergency shelter in an area currently lacking one, and by having a school likely to need less future repair. As well, at least one Mississippi school district agreed to loan out its buses to evacuate local residents to Red Cross shelters in the central part of the state, should the need arise. ${ }^{41}$ And, the Mississippi department of education plans to donate warehoused USDA food supplies to shelters when another emergency situation occurs. ${ }^{42}$

\footnotetext{
38 See, e.g., Interview with Glen East, Gulfport Sch. Dist. Superintendent, in Gulfport, Miss. (Oct. 19, 2006); Abigail Sullivan Moore, Spring Break Destination: The Land of Hurricane Katrina, N.Y. TIMES, Mar. 5, 2006, at 11. The contributions by faith communities across the country have been substantial, and some have described this level of activity as "the largest faith-based disaster response in the nation's history." See, e.g., Sean Mussenden, Storm Aid's a Mission: Virginians Join Faith-Based Disaster Response Called Largest Ever, Richmond TIMEs DisPaTcH, Oct. 22, 2005, at A4; Ben Caldwell, Church Volunteers Helping with Flood Relief, CHARLESTON GAZETTE, Oct. 26, 2005, at 1; Idaho Churches Offer Cars, Housing, and Jobs to Katrina Refugees, Associated PRess State \& Local Wire, Oct. 16, 2005; Good Works: Hurricane Aftermath, ATLANTA JoURnAL-ConstituTion, Sept. 24, 2005, at 5 F.

39 Frye, School may double, supra note 33.

40 Id.

41 Jackson County Offers Free Bus Evacuation This Hurricane Season (WLOX television broadcast June 25, 2007).

42 Brad Kessie, Hurricane shelters discussed at meeting (WLOX ABC 13 television broadcast May 30, 2007), available at http:/www.wlox.com/Global/story.asp?S=6582271.
} 


\section{B. Mississippi Schools' Role in Short-Term Recovery}

At the same time Mississippi school districts were helping to address their communities' immediate needs, school administrators began the difficult work of reopening schools. Most (if not all) of the Mississippi Gulf Coast area superintendents remained in the region during the storm. ${ }^{43}$ They began work to reopen schools within days of Katrina's landfall, when roads were still blocked by so much debris that often they were impassable. ${ }^{44}$

In the years leading up to Katrina, Mississippi school district superintendents from the Gulf Coast region had become better acquainted with one another through meetings and activities of the Mississippi Gulf Coast Education Consortium. ${ }^{45}$ After Katrina, they utilized that existing organizational structure, working together and often sharing information about the progress of insurance claims, FEMA and MEMA agents and programs, and various aspects of the recovery effort. ${ }^{46}$ Two days after Katrina, these superintendents convened at a meeting of the Consortium in Biloxi and began their post-Katrina cooperation. Fourteen months after Katrina when I attended a Consortium meeting, their camaraderie was evident.

Whether they realized it or not, many of the Mississippi Gulf Coast superintendents were united by shared assumptions about the ways in which schools could help anchor their communities in the short- and long-term as the hard work of rebuilding progressed. First, if school was back in session, parents and children in the community would have some sense of stability and familiarity for several hours a day during an otherwise chaotic existence. ${ }^{47}$ Natural disasters like Katrina cause extraordinary levels of stress on individuals, and

\footnotetext{
43 Telephone Interview with Tom Clark, Executive Dir. of the Gulf Coast Educ. Initiative Consortium (Oct. 2006).

${ }_{44}$ See, e.g., Robinson Interview, supra note 29.

45 Clark Interview, supra note 43.

46 Kim Stasny, Who Was Not Touched?, in BAY WAVELAND Schools ONE YEAR REPORT (Fall 2006).

47 See, e.g., Telephone Interview with Kim Duffy, Atty. for Miss. Ctr. for Justice and parent of school-aged children (Oct. 27, 2006).
} 
especially on children. ${ }^{48}$ After a disaster, the more children are able to return to a familiar routine, even if only in school, the more manageable the disruptions to their lives become. ${ }^{49}$ (For high school students especially, those who do not attend school regularly after such a large-scale disaster are more likely to become permanent dropouts. ${ }^{50}$ ) Having school back in session was a daily event with a significance that was almost tangible. As one parent and community organizer explained, "the day my kids went back to school was when we knew things would be normal again." 51

Second, having schools-especially good schools-back in session also meant that in many cases, families would be more likely to stay in the community or return to it. ${ }^{52}$ During the weeks and months after Katrina, parents were battling the bureaucracy of insurance companies and FEMA; attempting to

48 See, e.g., Kenneth B. Wells and Greer Sullivan, Healing Storm Victims'Mental Health, NEWSDAY, Oct. 3, 2005.

${ }^{49}$ Lewis Aptekar, The Emotional Effects of Disaster on Children: A Review of the Literature, 19 INT'L J. OF MENTAL HEALTH 77 (1990); Gretchen Hoffman, School can Help Displaced Students Cope, Pasadena STaR-News, Sept. 17, 2005; Emma Daly, Helping Students Cope With a Katrina-Tossed World, N.Y. TIMES, Nov. 16, 2005, at B3.

50 In early November 2005, the Louisiana Department of Education estimated that about 20,000 children were, because of Katrina, not attending school anywhere. The News Hour with Jim Lehrer (PBS broadcast Nov. 1, 2005); Shelia Dewan, For Many, Education Is Another Storm Victim, N.Y. TIMES, June 1, 2006, at A16. A study conducted about six months after Katrina concluded that of a group of New Orleans evacuees dispersed throughout southern Louisiana, "nearly one in four school-age children is either not enrolled in school or misses 10 days of class every month. Many who do attend school in their temporary host communities find the classrooms overcrowded, the staff exhausted and stress levels unbearably high." Redlener, Orphans, supra note 18, at A27.

51 Duffy Interview, supra note 47; see also STENNIS INST. OF Gov'T, SPECIAL REPORT, supra note 6 , at iv.

52 Shelia Dewan et al., Evacuees' Lives Still Upended Seven Months After Hurricane, N.Y. TIMES, Mar. 22, 2006, at A1; Leslie Eaton, 10,000 Get Grant Letters On Rebuilding in Louisiana, N.Y. TIMES, Dec. 1, 2006, at A24; Leslie Eaton, Hurricane Aid Finally Flowing to Homeowners, N.Y. Times, July 17, 2006, at A1; Matt Fellowes et al., The State of New Orleans: An Update, N.Y. TIMES, July 5, 2006, at A17; New York Times Editorial Board, Editorial: Still Battering the Katrina Homeless, N.Y. TIMES, Apr. 29, 2006, at A10; Gary Rivlin, New Orleans Commission to Seek Overhaul of Schools and Transit, N.Y. TIMES, Jan. 11, 2006, at A1; Duffy Interview, supra note 47; News Hour, Nov. 1, 2005, supra note 50 (describing New Orleans in early November 2005 as "virtually childless"). 
get help from the Red Cross and other relief agencies; and trying to return to work or seek new employment with FEMA or other employers. When schools were open, parents could be comfortable with the knowledge that while they attempted to hold their families' lives together economically, their children would be supervised for several hours every day. ${ }^{53}$ Additionally, those parents employed by school districts would receive paychecks. Because, like students, not all teachers and staff returned, some school districts were able to promise all teachers and staff who stayed that they would not be laid off during that school year. ${ }^{54}$ The economic impact of reopening or creating good schools extends beyond the jobs it provides for teachers and staff, though: as education researchers Paul Hill and Jane Hannaway have written, "re-emerging or new businesses will be able to attract high-caliber workers only if the schools their children can attend are good." 55

Third, when schools reopened, they could care for their students in a variety of ways. Many districts' administrators worked with state authorities to have all of their students declared eligible for free and reduced meals, thus enabling schools to provide students one or two hot meals per day at no cost to their families. For some students, these were the first hot meals they had eaten since the hurricane hit six weeks earlier. ${ }^{56}$ Providing for children in this way bolstered parents' efforts to rebuild families' lives. As the next section will discuss, too, when school was back in session, teachers and staff could supplement the efforts of parents and help these children start

${ }^{53}$ New Orleans School Maintains High Standards in the Aftermath of Hurricane Katrina, ACHIEVER 1 (Oct. 1, 2006); see also STENNIS INST. OF GOV'T, SPECIAL REPORT, supra note 6 , at iv.

${ }_{54}$ See, e.g., Rodolfich Interview, supra note 36; Robinson Interview, supra note 29. In early 2006, New Orleans announced that over 7,500 employees would be laid off and their health benefits terminated. Sharon Porter Robinson \& Penny Engel, Creating World-Class Teachers: Prospects for Katrina Recovery and Beyond, in RoBINSON \& BROWN, supra note 6 , at 153 .

${ }_{55}$ Paul Hill \& Jane Hannaway, The Future of Public Education in New Orleans, AfTer Katrina: REBUILDING OPPORTUNITY AND EQUITY INTO THE NEW NEW ORLEANS 5 (Jan. 2006).

${ }^{56}$ See, e.g., Robinson Interview, supra note 29; U.S. Dep't of Agric., Emergency Feeding of School Children in Areas Devastated by Hurricane Katrina (Aug. 31, 2005). 
to come to terms with the disaster. ${ }^{57}$

The superintendents' local efforts and regional coordination were strongly supported at and reinforced by the state-level educational administration, as well. Researchers who have written about Mississippi's recovery have noted the high level of intra- and inter-governmental communication. The connection between the affected school districts and the state board of education exemplifies this. In addition to focusing on these problems from the state capitol complex in Jackson, Mississippi, the state superintendent made numerous visits to the Gulf Coast, maintaining a high level of communication with the local district superintendents. ${ }^{58}$

In total, forty-six Mississippi public school districts closed after Katrina hit on August 29, 2005. ${ }^{59}$ Thirty-nine of these districts reopened within one month, many of those within just a couple of weeks. $^{60}$ Of the remaining seven districts, most reopened in early- to mid-October 2005, and the last, the Bay St. Louis-Waveland district located where the storm hit the coast most directly, reopened in early November 2005. ${ }^{61}$ In many school districts, classes were held in some of the 466 mobile classroom units requested as a result of hurricane damage for days and weeks; in other districts, classes were being held in mobile units two years after Katrina. ${ }^{62}$

57 See also Margie Hunter, Schools Take in Displaced Students (CNN television broadcast Sept. 7, 2005); Margie L. Kiter Edwards, An Interdisciplinary Framework on Disasters and Stress: The. Promise of an Ecological Framework, 13 Soc. F. 115, 120 (1998); STENNIS INST. OF GOV'T, SPECIAL REPORT, supra note 6, at iv.

58 For at least two and a half months after Katrina, State Superintendent Hank Bounds turned the state board administration's energies to Gulf Coast recovery around the clock. Bounds Interview, supra note 2; STENNIS INST. OF Gov'T, SPECIAL REPORT, supra note 6 , at xii-xiv.

59 Miss. Dep't of Educ., Katrina Recovery Information, School Opening Dates (2005), available at: http://www.mde.k12.ms.us/Katrina/opening.html.

60 Id.

61 Id.

62 STENNIS INST. OF GOV'T, SPECIAL REPORT, supra note 6, at xi. 


\section{Katrina's Impact on Local Funding for Education in Mississippi}

As education officials were working to reopen schools, they also needed to think about how their districts-funded in large part by property taxes-were going to cover their own costs in the coming months and years. Much of their tax base had been washed out to sea or otherwise decimated, and per-pupil allocations from the state could vary considerably in the future, depending on students' rate of return. About thirty percent of Mississippi public school funding comes from local tax revenue, generally a combination of commercial and residential property tax and also sales tax. ${ }^{63}$ Federal funding was intended to help damaged districts cover temporary costs associated with reopening a school district or to assist districts in educating displaced students, not to provide for rebuilding or to counter the effects on the property tax base. ${ }^{64}$ And, in the years leading up to Katrina, local districts had to dip into their own coffers because education was not "fully funded" in Mississippi until 2007; as a result, local districts did not enter into Katrina with substantial reserves. ${ }^{65}$

Before Katrina, the biggest commercial players on the Mississippi Gulf Coast were the casinos, a few large

63 Handout from Andrew Mullins, Executive Assistant to the Chancellor and Assoc. Prof. of Educ., Univ. of Miss. (2006) (on file with author).

64 U.S. Dep't of Educ., Helping Gulf Coast Students, supra note 19 (reporting that over $\$ 750$ million of federal aid was provided pursuant to the Immediate Aid to Restart School Operations Program); Michelle R. Davis, Democrats Seek Education Dept. 'Recovery Czar', EDUC. WEEK, May 3, 2006; Michelle R. Davis, Gulf Coast Districts Get Restart Aid, But Ask Whether It Will Be Enough, EDUC. WEEK, Mar. 29, 2006, at 28; Klein, Schools, supra note 26, at 1, 28.

65 This is what is meant by education in Mississippi being "fully funded" or not: the state established an education funding scheme under which the state would contribute more to particularly poor districts, if those districts were taxing themselves at a certain level and still could not generate a certain per-pupil expenditure. The funding scheme was the result of an innovative approach led in the mid-1980s by Governor William Winter. But, similar to having a line of credit and not using it all, the state would authorize its own ability to allocate a certain level of funding, but then not actually approve that level of funding when it came time to balance the budget. Bounds Interview, supra note 2; Robert C. Johnston, Education Budget to See Increase, EDUC. WEEK, June 7, 2006. 
manufacturers such as shipbuilder Northrop Grumman, and nationwide chain stores including Home Depot and Wal-Mart. ${ }^{66}$ After Katrina, the state government was quick to recognize the role of casinos in strengthening the pre-Katrina Gulf Coast economy. Even anti-gaming Governor Haley Barbour strongly supported the legislative resolution that allowed casinos to be built for the first time onshore (as opposed to offshore on floating barges or riverboats) as long as they were within eight hundred feet of water. ${ }^{67}$ This concession allowed casino rebuilding to commence even more quickly because the casinos could construct buildings that were more likely to withstand future storms. Thousands of construction jobs were created within weeks after Katrina. ${ }^{68}$ Many casinos were able to open within several months; one year after Katrina, 13,000 of the former 15,000 jobs in the casinos had returned. ${ }^{69}$ In the twenty-two months following Katrina, the casinos invested almost $\$ 1.5$ billion to rebuild their businesses on the Mississippi Gulf Coast. $^{70}$ Their investment paid off: as the second anniversary of Katrina approached, Mississippi casinos were generating alltime revenue highs, ${ }^{71}$ and also putting money back into local school districts' coffers via local tax revenue. ${ }^{72}$

Similarly, shipbuilder Northrop Grumman, the state's largest private employer, maintained its presence on the coast although its workforce shrunk by nearly ten percent, apparently because of a shortage of skilled labor. ${ }^{73}$ Not all large commercial

${ }^{66}$ See, e.g., Robertson, Coastal Cities, supra note 8.

67 News Hour, Aug. 25, 2006, supra note 14.

68 George Penick \& K. Jack Riley, Mississippi Comeback, L.A. TIMES, Aug. 20, 2006.

${ }^{69}$ Kathy Hanrahan, Miss. Coast Casino Employees Returning, Still Face Challenges, ASSOCIATED PRESS STATE \& LOCAL WIRE, Sept. 9, 2006.

70 Vendors Excited About Post Katrina Casino Resurgence (WLOX broadcast July 3, 2007).

71 Gary Rivlin, Casinos Booming in Katrina's Wake as Cash Pours In, N.Y. TIMES, July $16,2007$.

${ }^{72}$ News Hour, Aug. 25, 2006, supra note 14.

${ }^{73}$ Debbie Elliott, Gulf Coast Economics Reshaped by Katrina, All Things Considered (NPR broadcast May 26, 2007); Geoff Pender, Coast's Economic Outlook Positive: Rebuilding Efforts Boosting Economy, SUN HERALD, Dec. 27, 2006. 
enterprises stayed on the Mississippi Gulf Coast. ${ }^{74}$ But, when "big box" stores reopened, the impact on the local economy was almost palpable, not only because these stores could provide inexpensive food, clothing, and general drugstore items (WalMart) or construction materials (Home Depot, Lowes), but also because a not-insignificant amount of the commercial tax base returned without years of delay. ${ }^{75}$ And, in a few districts, unusual circumstances made the funding impact more tolerable. For example, because Katrina destroyed an estimated halfmillion vehicles all along the Gulf Coast region ${ }^{76}$ and car insurance companies paid out on claims comparatively quickly, car dealerships in the area were able to sell non-flood-damaged cars almost as fast as they could get them in stock. For school districts with car dealerships in their boundaries this was a boon. ${ }^{77}$

Not all school districts had a substantial commercial component to their local tax base, though. For example, Katrina's ground zero spanned the neighboring, heavily residential Bay St. Louis and Waveland communities and the one school district that ties them together. That school district's superintendent estimated that about sixty percent of the tax base from Bay St. Louis was completely destroyed, and ninety.

\footnotetext{
74 Vacuum manufacturer Oreck Corporation left for Tennessee, and in Pass Christian neither the community's only Wal-Mart nor its Winn Dixie grocery store had been rebuilt nearly two years after Katrina, although plans to rebuild the Wal-Mart existed at the time this went to press. Debbie Elliott, Katrina Still Bad for Business in Pass Christian, All Things Considered (NPR broadcast May 27, 2007); Elliott, Gulf Coast Economics, supra note 73.

75 In some towns, a few large businesses can make up most of the property and/or sales tax base: for example, in the small town of Pass Christian, before Katrina the WalMart and Winn Dixie grocery store accounted for seventy-five percent of local sales tax revenue. Melissa Block, Mississippi Mayor Hails Return of Wal-Mart, All Things Considered (NPR broadcast Mar. 1, 2007) (quoting Pass Christian, Mississippi, Mayor Leo McDermott); News Hour, Mar. 20, 2006, supra note 4; Anne D'Innocenzio, Home Depot and Lowe's Plan Big Role In Rebuilding Of Gulf Coast, Associated PRESS STATE \& LOCAL WIRE, Oct. 17, 2005.

76 Tamara Lush, Hurricane's Scars Will Linger on Cars, St. PETERsBuRg Times, Nov. 27, 2005, at $1 \mathrm{~B}$.

77 The Jackson County school district was one of these. In fall 2006 , it anticipated almost covering the drop in property tax revenue with tax revenue from the sale of thousands of vehicles. Robinson Interview, supra note 29.
} 
two percent from Waveland. Before Katrina, Waveland had a population of 10,000; one year later, it had only 2,500 residents and, none of the forty-one businesses had returned. ${ }^{78}$ Even the local municipalities in Bay St. Louis and Waveland, with the exception of the schools and the school district administration, were relocating as far inland (and thus away from the former cities' centers) as they could. ${ }^{79}$ Fourteen months after Katrina, the local government offices and school district administration all were run out of trailers in the middle of their communities, a situation that did not appear likely to change anytime soon..$^{80}$

Yet, one year after Katrina, it appeared that property near the beach had quadrupled in value in Biloxi, ${ }^{81}$ and even destroyed homes in Bay St. Louis and Waveland reportedly were valued at a significantly higher rate than before the hurricane damaged them. ${ }^{82}$ To an extent this is counterintuitive: many homes apparently were worth more in an uninhabitable or barely habitable post-Katrina state than they were before; the costs of rebuilding spiked, particularly considering newly revised building codes; and insurance costs skyrocketed if insurance was even available. ${ }^{83}$ Interestingly, it appears that these rising property values can be explained mainly by two factors: first, the demand for housing far exceeds the supply. On the Mississippi Gulf Coast alone, 65,000 homes were completely destroyed ${ }^{84}$ and in response to the shortage, rental costs often doubled. ${ }^{85}$ Second, speculators and developers are buying up a not-insignificant portion of land that has not been available for decades, some

78 News Hour, Aug. 25, 2006, supra note 14.

79 Interview with Becky Ladner, Bay St. Louis-Waveland Sch. Dist. Assistant Superintendent, in Bay St. Louis, Miss. (Oct. 19, 2006).

80 Id.; News Hour, Aug. 25, 2006, supra note 14.

81 News Hour, Aug. 25, 2006, supra note 14.

82 Ladner Interview, supra note 79.

83 In mid-2007, State Farm announced that it will not issue any new homeowners insurance policies in the entire state of Mississippi. Elliott, Gulf Coast Economics, supra note 73; Debbie Elliott, State Farm Moves Provoke Insurance Debate, All Things Considered (NPR broadcast Feb. 17, 2007); Madeline Brand, 'Marketplace' Report: Gulf Coast Insurance, Day to Day (NPR broadcast Feb. 15, 2007).

${ }_{84}$ News Hour, Aug. 25, 2006, supra note 14.

${ }_{85}$ Alix Spiegel, Stuck and Suicidal in a Post-Katrina Trailer Park (NPR broadcast Aug. 29, 2007). 
with an eye towards creating upscale condo developments. ${ }^{86}$ Some residents fear the dynamics could lead to "the largest transfer of property since the Great Depression." 87

On one hand, this increase in property values could substantially benefit local school districts because districts receive a large portion of their funding from local property taxes (assuming that owners can be found and can and will pay taxes on the higher, reassessed value of their property). But, an increase in property value also could serve to push long-time residents out of the area if they cannot afford to rent housing or to buy, rebuild, and/or pay higher property taxes-as many now cannot. ${ }^{88}$ Stated more bluntly, this effect could push many working-class and middle-class families and their children out of school districts that may in the near future have more revenues to spend on education after the bulk of Katrina recovery is completed. This is not to say that these school districts will have per-pupil spending rates anywhere near the nation's highest, ${ }^{89}$ or that the Mississippi Gulf Coast will "gentrify" overnight; many factors operate to deter such an effect. ${ }^{90}$ Yet, it seems quite likely that the demographic profile of the region's students will change substantially. ${ }^{91}$ However, at the time this

86 Elliott, Gulf Coast Economics, supra note 73.

87 Elliott, Katrina Still Bad for Business, supra note 74.

${ }_{88}$ See generally Melanie Peeples, Hurricane Season Sparks Survival Training, Morning Edition (NPR broadcast June 11, 2007); Elliott, Gulf Coast Economics, supra note 73; Spiegel, Stuck and Suicidal, supra note 85.

89 Mississippi consistently ranks at or near the bottom of all fifty states and the District of Columbia in per-pupil spending. See, e.g., Nat'l Ctr. for Educ. Statistics, Revenues and Expenditures for Public Elementary and Secondary Education: School Year 2002-2003, Table 5: Student Membership and Current Expenditures Per Pupil in Membership for Public Elementary and Secondary Schools, by Function, State, and Outlying Areas: School Year 2002-2003 (Oct. 2005), available at: http://nces.ed.gov/ccd/pubs/npefs03/findings.asp\#3.

90 Among these factors are that the rate of construction is slow and also that families often are reluctant to move elsewhere even if, like a reported 100,000 people in Mississippi, they still lived in FEMA trailers one year after Katrina because many of them could not afford the significantly higher post-Katrina rental prices across the region. Hanrahan, Miss. Coast Casino Employees, supra note 69; Spiegel, Stuck and Suicidal, supra note 85.

91 For example, the housing shortage and resulting skyrocketing rental prices reportedly have driven out many low-income families. Especially in New Orleans, 
article went to press, extensive demographic information was available only for the 2005-2006 school year, the year in which Katrina hit. ${ }^{92}$

\section{Addressing Students' Mental Health Needs in Mississippi}

Perhaps one of the greatest lessons we can learn from Katrina is that functioning schools create an unparalleled opportunity to provide mental health services to children after such a disaster. Understandably, when providing food and shelter for one's children are real, daily concerns for parents, and when securing funding and labor to repair and rebuild basic school facilities lead the list of superintendents' priorities, attending to students' mental health needs can seem like a luxury. But, because schools can provide a substantial normalizing force in students' lives merely by holding classes, ${ }^{93}$ it is important to recognize the positive impact that schools can have on students' mental health at a crucial point in time-and to take advantage of this unique opportunity. ${ }^{94}$ As psychiatrists Kenneth B. Wells and Greer Sullivan have written, "mental

African-Americans are disproportionately poor. And the construction boom has brought a substantially higher number of Latino children to the area as those children travel with their families, creating the possibility that districts may have increasing numbers of children with limited English proficiency. Spiegel, Stuck and Suicidal, supra note 85.

92 Hundreds of thousands of families with school-age children remained in transition during that school year and data often was reported at non-standard times out of practical necessity. School districts' enrollments (particularly in New Orleans, where families and children were slower to return) varied wildly throughout that school year.

93 News Hour, Apr. 6, 2006, supra note 1 (School "has been like therapy to me," said Principal Ricky Reed, and "an escape" for students, as well.); see generally Aptekar, The Emotional Effects, supra note 49; John Pope, Katrina Kids Can Recover; Mental Health Pros Offer Post-Storm Aid, TIMES-PICAYUNE, Aug. 11, 2006, at 1.

94 RAND News Release, RAND Toolkit Identifies Programs for Long-Term Recovery Among Children Exposed to Significant Traumatic Events (Oct. 24, 2006) ("We found that following Hurricanes Katrina and Rita, schools were in a unique position to help the displaced students they enrolled, but had limited information about how to help,' said Lisa Jaycox, a RAND senior behavioral scientist. . . . [a]lthough schools have developed good capacity as 'early responders' to support communities in the aftermath of disasters or crises, they have much less experience in how to support the longer term mental health issues of students and staff members."). In the immediate aftermath of the hurricane, the National Association of School Psychologists emphasized the role schools could serve in helping students cope with Katrina. Hunter, Schools Take in, supra note 57; see also Edwards, An Interdisciplinary Framework, supra note 57, at 115, 120. 
disorders and psychological reactions to disasters are common and have an enormous impact that extends to quality of life and economic recovery." ${ }^{55}$

In the two years after Katrina, several studies focused on survivors' mental health, and some on children. ${ }^{96}$ These studies appear consistent with previous work evaluating connections between disasters and mental illness, which generally show that an increased level of mental illness often occurs among groups of people who have experienced disasters compared to those who have not, especially among vulnerable populations such as children; however, determining a specific level or rate of causation is incredibly challenging. ${ }^{97}$ Anecdotal evidence buttresses these conclusions further. ${ }^{98}$ Not all post-disaster

95 Kenneth B. Wells \& Greer Sullivan, Commentary, NEwsDay, Oct. 3, 2005.

96 The Columbia University Mailman School of Public Health study focused on New Orleans evacuees and noted that "nearly half of the parents surveyed reported that at least one child in the household had emotional or behavioral difficulties that he or she didn't have before the hurricane, such as feeling sad or depressed, being nervous or afraid, or having problems sleeping or getting along with others." David Abramson \& Richard Garfield, On the Edge: Children and Families Displaced by Hurricanes Katrina and Rita Face a Looming Medical and Mental Health Crisis (Apr. 2006). In March 2007, Dr. Irwin Redlener, a professor at Columbia University's Mailman School of Public Health which conducted the study released in 2006, commented that the mental health problems in Mississippi were more obvious than in Louisiana and characterized the health crisis in the region as "the most significant domestic crisis that we've seen in a very long time." Ryan Lafontaine \& Joshua Norman, Health Crisis: 'People Here Are Still Struggling', SUN HERALD, Mar. 16, 2007. Similarly, an August 2006 study by Harvard Medical School conducted one year after Katrina found that "cases of mental illness doubled after the disaster." Natalie Chambers, Katrina's Aftermath, HousToN CHRON., Oct. 27, 2006, at A6.

97 Gadsen and Fuhrman, supra note 6, at 77-78 (discussing several such studies); compare Aptekar, The Emotional Effects, supra note 49, at 77.

98 A doctor who provided medical services to students aboard a traveling Winnebago along the Mississippi coast noted nearly fifteen months after Katrina that she continued to be "overwhelmed by the number of children needing mental health services," and some of these students appeared to be exhibiting clear PTSD symptoms. Dreifus, Attending to Sick Children, supra note 16, at F2. A few months after Katrina, school nurses reported a higher level of vague physical complaints, headaches and stomach aches. Daly, Helping Students, supra note 49, at B3. And, Mississippi's school safety director Robert Laird conceded that the rate of student-initiated violence at all Mississippi Gulf Coast schools was higher during the 2006-2007 school year following Katrina than during the 2005-2006 year in which Katrina hit. Ryan LaFontaine, Bay District Called Safe, One of State's Best, Expert Says, Sun HERALD, Dec. 1, 2006, at A2; see also Ladner Interview, supra note 79. 
student violence is attributable to PTSD or other anxiety disorders, but parents and schools should be able to recognize that a student's increased aggression, nightmares, difficulty sleeping or concentrating, self-imposed isolation from others, or physical illness may be a medical condition. ${ }^{99}$ Because mental health problems are recognized disabilities under the Individuals with Disabilities in Education Act (IDEA), students can receive additional services if they have a diagnosed mental illness.

Many Mississippi school districts provided their students with counseling funded by federal and private grants and supplemented with local district dollars. ${ }^{100}$ The Pascagoula School District worked with the nearby University of South Alabama; the Mobile, Alabama, Mental Health Center; and the Mobile County Public Schools to train its school counselors and design its own counseling program. ${ }^{101}$ The. Bay St. LouisWaveland School District used federal restart money to provide counseling for its employees and students. ${ }^{102}$ In some districts, certain positions were dedicated to the sole purpose of Katrina counseling. ${ }^{103}$ At the state level, the Mississippi Department of Education offered "response teams of qualified school counselors" and also notified school districts that they could submit applications for grants from Mississippi's $\$ 1.7$ million

${ }^{99}$ Eboni M. Zamani-Gallagher \& Vernon C. Polite, Still Waters Run Deep: Cracks in the Educational Pipeline for African American Students Post-Hurricane Katrina, in ROBINSON \& BROWN 48, supra note 6; Brian Friedman, School Disruptions May Leave Students Stressed; Symptoms of Anxiety Disorder Can Vary With Child's Age, TIMESPiCAYUnE, Sept. 29, 2005.

100 Ladner Interview, supra note 79; Rodolfich Interview, supra note 36; Interview with Herb Brown, Pascagoula High Sch. Guidance Counselor, in Pascagoula, Miss. (Oct. 20, 2006); see also Pascagoula School District, Program NARRATIVE: HuRricane KATRINA COUNSELING INITIATIVE (undated) (on file with author). The U.S.-based International Medical Corps trained over one hundred Mississippi educators in assisting children in dealing with Katrina. Daly, Helping Students, supra note 50.

101 Pascagoula School District, Disaster Counseling AND STREss MaNagement TRAINING ACTIVITIES, SEPTEMBER 2005-MARCH 2006 (undated) (on file with author); CD: Transcending Trauma After a Disaster: A Guide for Schools (Univ. of S. Ala. College of Educ. undated) (on file with author).

102 Davis, Gulf Coast Districts, supra note 66, at 28.

103 News Hour, Apr. 6, 2006, supra note 1; Brown Interview, supra note 100. 
Project School Emergency Response to Violence funds. ${ }^{104}$ Furthermore, in October 2006 the Red Cross announced that the remainder of the $\$ 2.4$ billion in Katrina donations it had received would be used to provide mental health services. ${ }^{105}$

Adequate funding for mental health services is necessary but not sufficient to address students' needs after a disaster. Although raising Americans' general level of awareness about mental health issues is a challenge beyond the scope of disaster planning, it is possible for local, state, and federal government officials, and especially school district administrators, to learn more about the ramifications of disasters for their students' mental health. ${ }^{106}$ Understanding more about the reality of Katrina survivors' experiences can help accomplish that purpose; Barbara Barbieri McGrath edited a book collecting young Katrina survivors' reflections on their own experiences as expressed through artistic and written work. ${ }^{107}$ Resources for educators and officials involved in disaster planning are available from many sources, including the RAND Corporation and The National Child Traumatic Stress Network. ${ }^{108}$

Fortunately, thousands of teachers have provided their students with tools for coping with Katrina; students making collages about their Katrina-related experiences in a Houston art class is just one example. ${ }^{109}$ But teachers also have indicated concern about their students' long-term mental health. ${ }^{110}$ As we look to the future, it is some of these teachers and their successors who can be provided with resources that will help avert a children's mental health crisis in the wake of another Katrina-like disaster.

104 Miss. Dep't of Educ., Katrina Recovery Information, Frequently Asked Questions (Nov. 4, 2005), available at: http://www.mde.k12.ms.us/Katrina/faq/index.html.

105 Chambers, Katrina's Aftermath, supra note 97, at A6.

106 See generally Wells and Sullivan, Commentary, supra note 95.

107 BARBARA BARBIERI MCGRATH, THE STORM (2006).

108 RAND, Rand Toolkit, supra note 94; National Child Traumatic Stress Network, available at http://nctsnet.org.

109 News Hour, Apr. 6, 2006, supra note 1.

${ }_{110} \mathrm{Id}$. 


\section{CONCLUSION}

Over fifty years ago, the Supreme Court stated memorably in Brown v. Board of Education that "education is perhaps the most important function of state and local governments." 111 In the immediate aftermath and short-term recovery period following Hurricane Katrina, the Mississippi Gulf Coast public school districts served a civic function much greater than the narrow instructional role we most often attribute to schools, performing vital tasks in their communities and thus helping to lay the groundwork for long-term recovery. The U.S. Department of Education reported that nearly two years after Katrina, ninety-nine percent of the schools in Mississippi that were harmed by Katrina were functioning again, as were ninetyfive percent of their counterparts in Louisiana including about fifty percent in New Orleans-although some of these schools were operating out of trailers in long-term temporary quarters as they awaited the reconstruction of permanent buildings. ${ }^{112}$ That is no small accomplishment.

Whether the Mississippi Gulf Coast will emerge from Katrina with the sort of "renaissance" as communities in Florida and South Carolina have been able to create after hurricanes devastated their communities is unclear. But, the Mississippi Gulf Coast has a better chance at a brighter future because of the role its public schools played in the immediate and shortterm recovery effort. ${ }^{113}$ Now, as the region moves forward, it must not forget that its students will always have Katrina as part of their childhood. And though it is far from perfect, we must not forget the model the Mississippi Gulf Coast schools have provided as anchors for rebuilding their communities.

¿11 Brown v. Bd. of Educ., 347 U.S. 483, 493 (1954). For a discussion of the public function of education as one of creating citizens, see Betsy Levin, Educating Children for Citizenship: The Conflict Between Authority and Individual Rights in the Public School, 95 YALE L.J. 1647 (1986); Susanna Sherry, Responsible Republicanism: Educating for Citizenship, 62 U. CHI. L. REV. 131 (1995); Peter D. Hart Research Assocs. \& The Winston Group, Ready for the Real World? Americans Speak of High School Reform 20 (2005).

112 U.S. Dep't of Educ., Helping Gulf Coast Students, supra note 19.

113 See generally S. EdUC. FOUND., EdUCATION AFTER KATRINA, supra note 6; STENNIS INST., SPECIAL REPORT, supra note 6. 
HeinOnline -- 77 Miss. L.J. 734 2007-2008 